\title{
Current Hydrochemical Regime of the Sevastopol Bay
}

\author{
N. A. Orekhova*, A. V. Varenik \\ Marine Hydrophysical Institute, Russian Academy of Sciences, Sevastopol, Russian Federation \\ *e-mail: natalia.orekhova@mhi-ras.ru
}

\begin{abstract}
Variability of nutrients and the carbonate system components in the Sevastopol Bay is considered based on the hydro and -chemical surveys' data obtained in Marine Hydrophysical Institute in 20072016. Their inter-annual and seasonal variations are assessed proceeding from the nutrients' data and carbonate system components. Our results permit to draw a conclusion that the anthropogenic component constitutes a predominant pressure upon the ecological state of the Sevastopol Bay. At that spatial distribution of the nutrients and the carbonate system components is also conditioned by the Chernaya River fresh waters in the inner part of the bay. It is shown that organic matter oxidation and the carbonates" dissolution resulting from strong eutrophication determine the modern state of the carbonate system in the Sevastopol Bay. The decreasing difference between the atmospheric and surface waters $\mathrm{pCO}_{2}$ provides the basis at which the bay ecosystem can soon become a source of carbon dioxide. The conclusion is that shift of equilibrium towards predominance of the organic component in the natural cycles, as well as the increasing anthropogenic influence upon the Sevastopol Bay ecosystem can negatively affect both its ecological and recreational status.
\end{abstract}

Keywords: Sevastopol Bay, nutrients, carbonate system.

Acknowledgements. The research was carried out within the framework of the State Order No. 0827 2014-0010 "Complex interdisciplinary research of oceanographic processes determining the functioning and evolution of the Black Sea and the Azov Sea ecosystems on the basis of modern methods for marine environment monitoring and grid technologies" ("Fundamental Oceanography" code) and RFBR research project 16-35-60006 mol a dk "Long-term changes in the carbon cycle characteristics of the Sevastopol Bay".

For citation: Orekhova, N.A. and Varenik, A.V., 2018. Current Hydrochemical Regime of the Sevastopol Bay. Physical Oceanography, [e-journal] 25(2), pp. 124-135. doi:10.22449/1573-160X-2018-2124-135

DOI: $10.22449 / 1573-160 X-2018-2-124-135$

(C) 2018, N. A. Orekhova, A. V. Varenik

(C) 2018, Physical Oceanography

Introduction. The Sevastopol Bay is a typical coastal area under heavy anthropogenic pressure due to maritime activity like navigation, seaports and docks. Domestic sewage and household wastewater outlets located in the bay provide additional flux of nutrients and fresh organic matter. Protection piers between the outer part of the bay and open sea restrict water exchange between the bay and sea [1]. Over the past 20 years in the bay ecosystem significant changes in hydrochemical (oxygen concentration, nutrients' levels in the water column), physicochemical (grain size, humidity, porosity, organic and inorganic carbon content in the bottom sediments) and biological characteristics [2,3] had happened which led to hypoxia and even anoxic conditions in the upper layer of bottom sediments, transformation of natural regimes and cycles $[4,5]$. The changes that occur in the Sevastopol Bay ecosystem in 1998-2006 are described in more detail in [1, 3].

In the present work the results of hydrologic and hydrochemical research carried out in the Sevastopol Bay over 10 years (since 2007) which include the analysis of variability of nutrients and components of carbonate system are considered. 
Nutrients are one of the main limiting factors of numerous processes occurring in the marine environment. Their budget determines the basic biological and biochemical characteristics of marine environment and their evolution [6], possibility of organic matter photosynthesis and oxidation. Due to this changes the carbon dioxide concentration determining the concentration and ratio of carbonate system components [7].

Carbonate system is a complex system of equilibriums including the reactions with atmospheric and surface waters carbon dioxide, as well as inorganic carbon and cations of calcium and magnesium [8].

The most representative characteristic reflecting the stability of the ecosystem and its ability to recover is dissolved inorganic carbon $(D I C)$ as the total content of dissolved inorganic carbon forms: $D I C=\left[\mathrm{HCO}_{3}{ }^{-}\right]+\left[\mathrm{CO}_{3}{ }^{2-}\right]+\left[\mathrm{CO}_{2}\right][9,10]$. The change in the content of one of $D I C$ components leads to a redistribution between the dissolved forms of inorganic carbon. Thus, under the natural conditions this parameter is not subjected to significant fluctuations and its any noticeable variations indicate a violation of the equilibrium of production-destruction processes and a change in the value of the flow of carbon dioxide. The increase of $\mathrm{CO}_{2}$ concentration leads to the $\mathrm{pH}$ decrease and water acidification, to the increase in the concentration of bicarbonate ions $\left(\mathrm{HCO}_{3}^{-}\right)$in accordance with the system of equilibria:

$$
\mathrm{CO}_{2(\mathrm{~g})} \leftrightarrow \mathrm{CO}_{2(\mathrm{aq})} \leftrightarrow \mathrm{CO}_{2(\mathrm{aq})}+\mathrm{H}_{2} \mathrm{O} \leftrightarrow \mathrm{H}^{+}+\mathrm{HCO}_{3} \leftrightarrow 2 \mathrm{H}^{+}+\mathrm{CO}_{3}^{2-} .
$$

The increase of $\mathrm{CO}_{2}$ concentration (due to organic matter oxidation and/or its input from the external sources) and, as a consequence, the increase of DIC provides the decrease of the ecosystem buffer capacity and its ability to absorb atmospheric carbon dioxide, which is reflected in changes in the hydrochemical regime and biodiversity $[7,10]]$.

For assessing the stability of the carbonate equilibrium system in the bay, such as $D I C$, partial pressure of carbon dioxide $\left(p \mathrm{CO}_{2}\right), \mathrm{pH}$ and total alkalinity $(A l k)$ are used.

The purpose of the work is to perform a complex analysis of spatial and temporal variability of nutrients and the components of carbonate system $\left(p \mathrm{CO}_{2}, D I C\right.$, $\mathrm{pH}$ and $A l k)$ in the water column to study the hydrochemical regime of the Sevastopol Bay ecosystem.

Materials and methods. The Sevastopol Bay is semi-enclosed water basin with restricted water exchange. Its depth at the entrance is $20 \mathrm{~m}$ and closer to the inner part it reduces to 4-5 m. Mean depth makes up $12.5 \mathrm{~m}$ at that. More detailed physical and geographical description is given in [1].

Samples were taken with Niskin bottles from the surface and bottom waters according to the stations scheme (Fig. 1). Inorganic nutrients (phosphates, silicon, nitrates and nitrites) were analyzed photometrically after filtering seawater samples through a membrane filter with $0.45 \mu \mathrm{m}$ pore size [11]. When determining the concentration of silicon, a correction for the salinity was applied. Ammonium nitrogen was determined using the modified Sagi -Solorzano method for the sea water, which is based on the phenol-hypochlorite reaction using sodium nitroprusside and sodium citrate [12]. Total alkalinity was determined by direct potentiometric titration, $\mathrm{pH}$ was determined potentiometrically in an open $40 \mathrm{ml}$ cell using $N B S$ scale, 
the calculation was performed taking into account the temperature correction [12]. A glass electrode was applied as a working electrode, and the reference electrode was filled with $\mathrm{KCl}$.

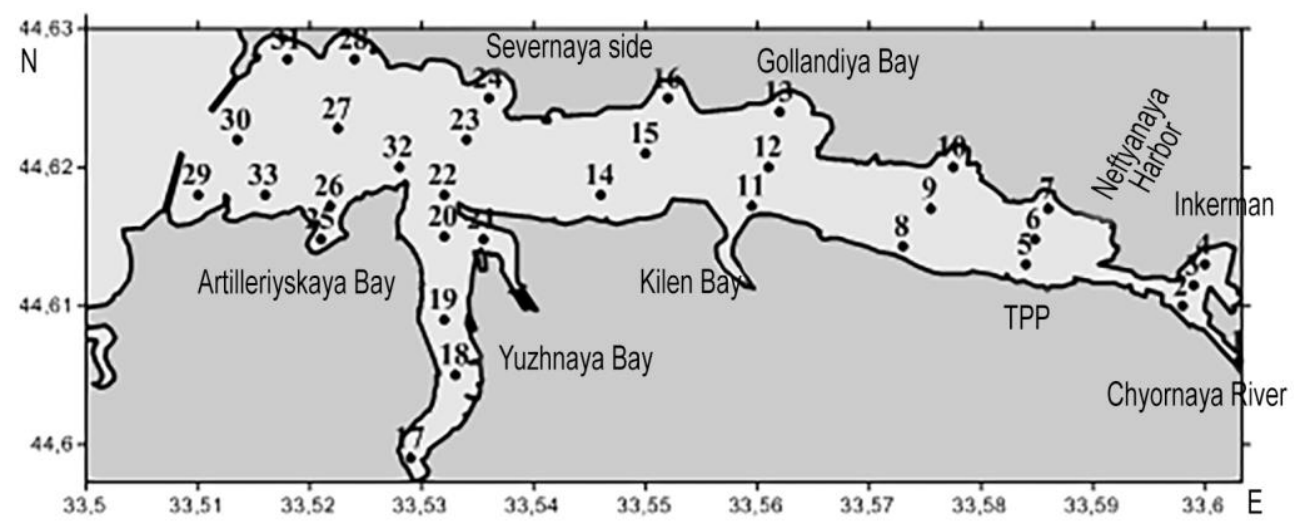

Fig. 1. Scheme of location of sampling stations

DIC, $\mathrm{CO}_{2}$ and $p \mathrm{CO}_{2}$ were calculated from $\mathrm{pH}$ and $A l k$ data $[5,8,9]$ using the carbonic acid constants recommended by the Department of Marine Sciences of UNESCO [13]. It was assumed that boron is a conservative element and its content is proportional to salinity. Therefore, the borate component of total alkalinity was calculated from the salinity [6]. The effect of the dissociation of water, phosphoric, sulfuric, hydrofluoric and other acids (present in small concentrations in sea water) on the alkalinity was not taken into account. The methods of carbonate system components are described in detail in $[12,13]$.

Results and discussion. Hydrochemical regime of the Sevastopol Bay determines the circulation of water directly inside the bay, the intensity of water exchange with the Black Sea waters, river and storm runoffs (as well as domestic wastewater discharge), atmospheric precipitation, etc. In addition, active navigation leads to disturbance and redeposition of bottom sediments. As a result of a combination of these factors, in the bay waters the concentrations of nutrients which are several times greater than their background values in the open sea are recorded. However, during the period under study the cases of exceeding the maximum permissible concentrations (MPCs) for fishery waters (the order of the Federal Agency for Fisheries No. 16326 of 09.02.2010) for nitrates and ammonium were not recorded, and for nitrites, phosphates and silicon these cases were single.

The range of changes in the concentration of inorganic forms of nitrogen in the bay waters is wide enough: $0.00-286.35 \mu \mathrm{mol} / \mathrm{dm}^{3}$ for nitrates, 0.00 $6.37 \mu \mathrm{mol} / \mathrm{dm}^{3}$ for nitrites, $0.00-40.70 \mu \mathrm{mol} / \mathrm{dm}^{3}$ for ammonium. The content of phosphates varied within the range of $0.00-5.20 \mu \mathrm{mol} / \mathrm{dm}^{3}$, the one of the silicon $-0.00-97.98 \mu \mathrm{mol} / \mathrm{dm}^{3}$.

The distribution of nutrients in the Sevastopol Bay waters is largely determined by the source of their input: by the Chernaya River runoff and discharge of domestic and storm wastewaters. This is evidenced from the spatial variability of nutrients. In 2007-2016 the maximum concentrations were recorded in the apex of 
Yuzhnaya Bay (station 17). Their concentrations in the surface waters were significantly higher than in the bottom ones due to lower density of river waters and wastewater. The increased content of nutrients in the Yuzhnaya Bay, in addition to the anthropogenic impact, is due to limited water exchange with the central water area of the Sevastopol Bay.

The maximum concentration of ammonium was detected in the areas affected by domestic sewage discharge and storm wastewaters (stations 17 and 25). In the area of fresh warm water discharge from local wastewater cogeneration plants (SDPP - State District Power Plant, station 8), the maximum of ammonium (more than 2 times higher than its concentration at station 17) was observed in the bottom layer, which is due to the recess in this area, contributing to the accumulation of pollutants. The maximum concentrations of silicon and phosphates are also characteristic of the surface layer of the southern part of the Yuzhnaya Bay (station 17) and the bottom layer in the SDPP area (station 8); moreover, the increased concentrations are recorded in the surface layer of the River Chernaya estuary (stations 14) and in the Artilleriyskaya Bay (station 25) in the area of domestic and storm wastewater discharges.

Despite the dependence of nutrient concentrations on the productiondestruction processes which have a pronounced seasonal course [14], its intraannual variations for various nutrients is different.
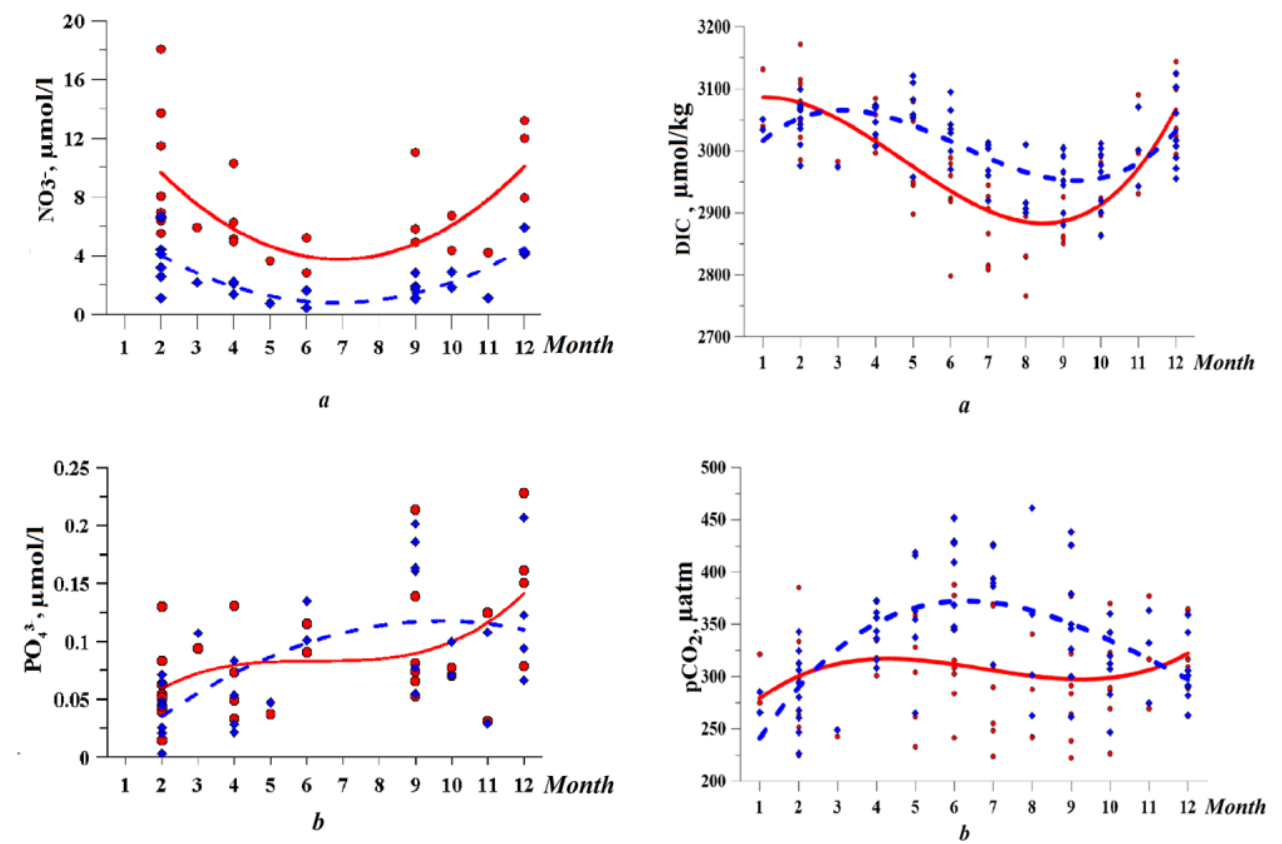

Fig. 2. Intra-annual variation of nitrates $(a)$ and Fig. 3. Intra-annual variation of $D I C(a)$ and phosphates $(b)$ in the Sevastopol Bay (the distri- $p \mathrm{CO}_{2}(b)$ in the Sevastopol Bay (see Fig. 2 for the bution in the surface layer is shown by red color, legend)

in the bottom one - by blue) 
In spring, the development of phytoplankton leads to a decrease in oxygencontaining forms of nitrogen, their minimum concentration is observed in the summer period (Fig. 2,a). In spring the concentration increases, the maximum values are determined in late autumn and winter periods. This is due to an increase in the contribution of river runoff, the intensification of vertical mixing processes, a decrease in temperature and light intensity that resulted in a decrease in the activity of photosynthesis in the upper layer and the mineralization of organic matter in the bottom one. During the entire year the concentration of nitrates in the surface layer was exceeded in comparison with the bottom one, which confirms the assumption of significant impact of river waters and wastewaters.

Intra-annual variation of the ammonium concentration on the surface and bottom waters is different. In the surface layer the increase of ammonium concentration from spring to winter period was noted. In the bottom layer, on the contrary, there is an increase in the ammonium from winter to summer with a further decrease in autumn. The increase in ammonium input with the coastal runoff with the beginning of the resort season, as well as a decrease in its consumption by phytoplankton in the upper layer of the bay water during the warm period [15] provide an increase of its concentration. In summer, the difference in concentrations between the surface and bottom layers reaches its maximum, which is due to the water stratification and a limited oxygen flux into the bottom layer. This leads to the fact that under conditions of lack of oxygen bottom sediments (as a result of organic matter bacterial destruction) become a source of reduced compounds, including ammonium ions. It should also be noted that in summer the concentration of ammonium in the bottom layer near the station 8 is practically by an order of magnitude higher than at other stations. With a decrease in temperature and enhanced hydrodynamic effect in late autumn and winter periods a "leveling" of the concentration of ammonium in the surface and bottom layers is observed.

The increased concentration of silicon on the surface waters during the autumn-winter period is mainly due to continental runoff: the maximum concentrations were observed during the flood period of the Chernaya River (December April). At the same time, the silicon concentration in the surface layer was two times higher than in the bottom one, which is most pronounced in the vicinity of the of river water inflow area (stations 1-4).

A tendency towards the increase from the winter period to the autumn one (Fig. 2, b) exists in the phosphates content on both horizons. In the surface layer a dramatic increase in the concentration was recorded in late autumn, in the bottom layer - in summer. At the same time, the maximum phosphates concentration on the surface exceeded the winter minimum at least by 2 times, at the bottom - by 3 times. In winter and autumn periods the phosphate concentration in the surface layer was higher than in the bottom one, but in summer, on the contrary, mean concentration in the bottom waters exceeded the one at the surface by more than $60 \%$, which is largely due to phosphate absorption by phytoplankton. Seasonal stratification of the bay waters maintains this difference. It should be pointed out that similar seasonal changes in phosphate concentrations are somewhat contrary to the well-known regularity according to which the maximum concentrations fall on the winter period due to removal from the underlying layers, as well as insignificant 
consumption of phosphates; with the temperature increase from spring to summer period, the phosphate content should decrease sharply due to hydrodynamic impact reduction and their active consumption in the photosynthesis process. Probably, this discrepancy is caused by the presence of additional anthropogenic sources of phosphates.

Thus, the intra-annual change of the nutrients in the Sevastopol Bay waters is determined not only by natural factors, including the inflow with river runoff and consumption by phytoplankton, but also by additional inputs from domestic sewages, storm wastewaters and atmospheric precipitation.

The classical ratio of nutrients for phytoplankton Si:N:P is 31:15.5:1 [16]. However, for the Sevastopol Bay waters this ratio differs significantly and is 50: $82: 1$, which implies that for the bay ecosystem, in conditions of a significant predominance of inorganic nitrogen in the water, inorganic phosphorus may be the main limiting nutrient. Correspondingly, the change in its concentration in the water area has the greatest effect on the bay carbonate system.

Carbonate system components. In addition to physical factors (mixing processes), DIC value depends on the chemical and biological processes of photosynthesis and the organic matter destruction:

$$
\begin{aligned}
& 6 \mathrm{CO}_{2}+6 \mathrm{H}_{2} \mathrm{O} \leftrightarrow \mathrm{C}_{6} \mathrm{H}_{12} \mathrm{O}_{6}+6 \mathrm{O}_{2}, \\
& \mathrm{C}_{6} \mathrm{H}_{12} \mathrm{O}_{6}+6 \mathrm{O}_{2} \leftrightarrow 6 \mathrm{CO}_{2}+6 \mathrm{H}_{2} \mathrm{O} .
\end{aligned}
$$

Carbon dioxide, which gets from the atmosphere, dissolves in the surface waters and is involved into the photosynthesis (2) spending on the organic matter production. Phosphates that get into the bay water with the Chernaya River, domestic and storm wastewaters are the limiting factor of photosynthesis in the Sevastopol Bay. In the bottom layer DIC value is determined by organic matter oxidation (3) which is accompanied by carbon dioxide concentration increase and oxygen consumption.

The organic matter concentration in the bottom layer depends on the intensity of photosynthesis on the surface and the intake of fresh organic matter with external sources (domestic, storm, river runoff, etc.). In addition, its level is determined by the presence of oxygen, which provides the reduction of the suspended matter flux to the bottom as a result of organic matter mineralization in the photic layer. In its turn, oxygen concentration in the water column is determined by the temperature (as the gas solubility decreases with the temperature increase) and hydrodynamic effect providing its entry to the bottom layer. In case of the oxygen deficiency in the water column for the oxidation of the entire organic matter, its accumulation in the bottom sediments (which most often can subsequently become a source of carbon dioxide for the bottom layer) takes place. At the present time a low oxygen concentration (less than 30\% saturation, or $63 \mu \mathrm{mol} / \mathrm{l}$ ) and high content of organic matter (more than $4 \%$ by dry weight) are observed in the bottom sediments of the bay [4].

Seasonal dynamics of carbonate system components is shown in Fig. 3. As expected, DIC in the surface waters of the Sevastopol Bay is lower than at the bottom (Fig. 3,a), which is determined by the consumption of inorganic carbon during the photosynthesis (2) in the upper layer and oxidation of organic matter (3) in the bot- 
tom one. Seasonal variability was not pronounced and did not exceed $6 \%$ in different seasons of the year.

The most obvious changes are characteristic for the surface layer, which is due to its dynamism and various sources of $\mathrm{CO}_{2}$ (river runoff, domestic and storm water discharge). In winter, the decrease in light and phosphates concentration (Fig. 2, b) and, as a result, the photosynthesis deceleration (not least because of the gas solubility increase) provide the maximum of DIC (Fig. 3, a). In addition, bicarbonates make the main contribution ( $\sim 90 \%)$ to $D I C$ and its source is the Chernaya River runoff. The increase of its content falls precisely on the high water period of the Chernaya River (December - April). DIC minimum is observed in summer due to active photosynthesis maintaining by additional input of nutrients with domestic wastewater and light activity. During this period the impact of the Chernaya River waters, which are a source of dissolved carbon dioxide and bicarbonates, is minimal. The maximum of $D I C$ at the river mouth indicate a significant impact of the River Chernaya waters on the hydrochemical characteristics of the Sevastopol bay. The river waters are not only a source of inorganic carbon but also of fresh organic matter that deposits near the mouth of the Chernaya River and, being oxidized, also makes an appreciable contribution to DIC.

A pronounced seasonal stratification restricts the oxygen flux which gets to the bottom layer. Due to this fact, the amount of oxygen getting into the layer is not sufficient to oxidize the entire organic matter (equation (3)), which leads to its accumulation in the bottom sediments. The observed increase in DIC in the surface layer during the autumn (Figure 3,a) is probably the result of organic matter oxidation in the bottom sediments and $\mathrm{CO}_{2}$ input into the bottom and surface layers due to vertical mixing.

It should be pointed out that in autumn-winter period vertical mixing of waters results in DIC homogeneous distribution in the bottom and surface layers (Fig. 3, a).

$\underline{p \mathrm{CO}_{2}}$ in the surface layer has very noticeable seasonal fluctuations (Fig. 3, $b$ ), which are resulted from a change in the activity of the chemical and biological processes, temperature regime and hydrodynamic impact. In the bottom layer in spring and winter $p \mathrm{CO}_{2}$ levels were similar and corresponded to the minimum values, in spring and summer - to the maximum ones (Fig. 3, b). Considering the seasonal dynamics, we can notice the fact that the greatest difference (confirmed by statistic calculations) in $p \mathrm{CO}_{2}$ in the surface and bottom layers is observed in summer period: the maximum - in the bottom layer, the minimum - in the surface one. This is the result of a combination of several factors: carbon dioxide solubility decrease with the temperature increase and photosynthesis intensification which lead to the decrease of carbon dioxide concentration and, correspondingly, to the decrease of $p \mathrm{CO}_{2}$ in the upper layer; more active oxidation of organic matter with the temperature increase in the bottom layer despite the decline of oxygen flux leading to $p \mathrm{CO}_{2}$ increase; water stratification due to hydrodynamic effect weakening.

In addition to the abovementioned parameters for estimating the components of the carbonate system and the factors that determine their current state, total alkalinity value, which depends to a great extent on the salinity and concentration of the carbonate ion supplied with terrigenic sources, river runoff and decomposition of carbonates in the bottom sediments, is of a great interest. Alk value is not affected by the $\mathrm{CO}_{2}$ at that [8]. In the Sevastopol Bay the greatest effect on its value is 
exerted by the Chernaya River waters as a source of carbonate and bicarbonate ions, which manifests itself in its maximum value in the surface layer in winter. In general, Alk distribution over the depth is rather homogeneous.

The analysis of the seasonal dynamics of the carbonate system components showed that in summer they are determined primarily by the chemical and biological processes of photosynthesis and organic matter oxidation, in winter - by the flood runoff of the Chernaya River (December - April). Moreover, in winter and autumn the vertical distribution of carbonate system components is rather homogeneous; this is due to the mixing processes.

In addition to natural factors, anthropogenic influence contributes to the spatial variability of the Sevastopol Bay carbonate system components. At its edge the Sevastopol Bay takes the Chernaya River waters (Fig. 1), which largely determines the hydrochemical characteristics of this area (stations 1-4): the increased values of DIC, $p \mathrm{CO}_{2}$, Alk and $\mathrm{pH}$ decrease in the surface layer. This is the result of organic matter oxidation brought with the Chernaya River waters and photosynthesis limitation in spite of high concentration of nutrients. With the distance from the bay edge to the exit therefrom into the seaward part $T \mathrm{TO}_{2}, p \mathrm{CO}_{2}$ and $A l k$ decreases whereas $\mathrm{pH}$ increases. The exception is Inkerman and the Yuzhnaya Bay areas (stations 8 and 17, respectively). Sharp changes in the values of the carbonate system components in these areas are due to the anthropogenic impact of sewage discharge, as well as the location of production sites where ship repairing and moorage are carried out. The maximum DIC, $p \mathrm{CO}_{2}$, Alk values and the minimum $\mathrm{pH}$ in the surface layer of the Yuzhnaya Bay apex indicate the presence of the source of waters enriched with nutrients, fresh organic matter and bicarbonates. According to $p \mathrm{CO}_{2}$ value $(\sim 500 \mu \mathrm{atm})$ it can be assumed that in the Yuzhnaya Bay waters $\mathrm{CO}_{2}$ evasion takes place.

The location of SDPP (station 8), which results to the discharge of fresh warm waters, largely determines hydrochemical features of this region. The presence of deepening here also contributes to the formation of a concentration gradient between the bottom and surface layers, which leads to the hypoxia appearance, accumulation of organic matter and other pollutions in the bottom layer. In the bottom sediments this results in the appearance of anaerobic conditions [4].

In accordance with the temporal variability of the Sevastopol Bay water hydrochemical characteristics, the decrease in ammonium and silicon concentrations in 2007-2012 with the subsequent increase by 2016 on both the surface and the bottom layers were recorded. A significant difference in the concentrations at the surface and bottom waters is characteristic of ammonium in 2007-2010, in 2007 it was 80\%. The decrease in the ammonium concentration in the bottom layer reached $86 \%$ by 2011. Then, by 2016 its threefold increase took place. In the surface layer from 2007 to 2016 there was than twofold increase of ammonium concentration.

A long-term variations of nitrates concentration on both horizons is generally characterized by a decrease from 2007 to 2009, and then by a steady growth from 2011 to 2016 (Fig. 4, a). At the same time, inter-annual difference in concentrations in the surface layer is more pronounced. Three periods can be distinguished in the change in the phosphates in the waters of the bay (Fig. 4, b): from 2007 to 2009 the concentration increased 1.5-2 times on the surface and near the bottom, then it 
decreased by 2012 and sharply increased by 2016. In addition, in 2016 in both surface and bottom layers phosphate concentration was 2.5 times higher than in 2012.

Over the past 10 years on there is a trend to the increase of DIC, $p \mathrm{CO}_{2}, A l k$ and $\mathrm{pH}$ decrease in the carbonate system. It is most pronounced in the surface waters (Fig. 5).

Since $2007, D I C$ has increased by $\sim 5 \%$ (in the surface and bottom layers), the increase is especially pronounced in the autumn. This is already quite significant value, indicating the negative changes taking place in the bay ecosystem. DIC increase is also due to the rise of the level of both atmospheric and dissolved $\mathrm{CO}_{2}$ due to the contribution of natural and anthropogenic factors.
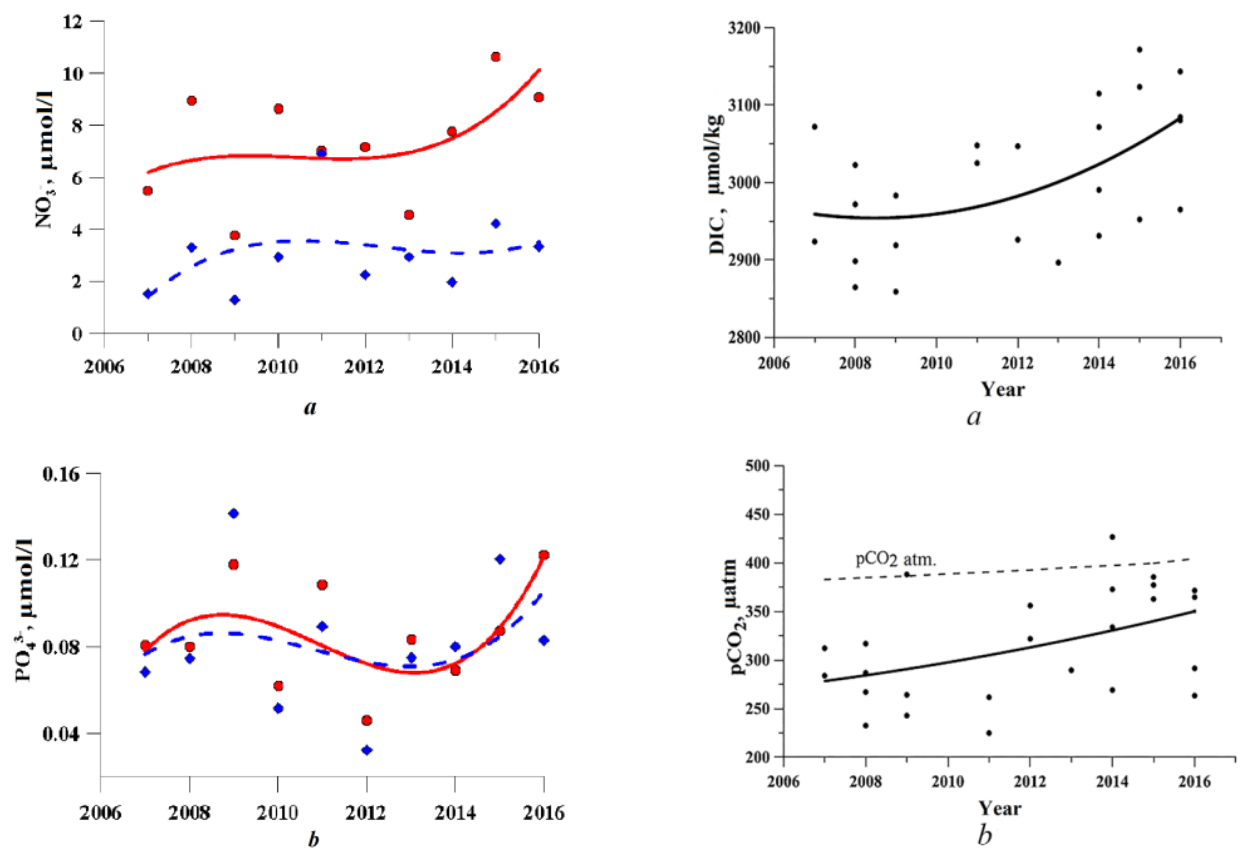

Fig. 4. Inter-annual variations of nitrates $(a)$ and phosphates $(b)$ in the Sevastopol Bay (see Fig. 2 for the legend)

Fig. 5. Inter-annual variation in $D I C(a)$ and $p \mathrm{CO}_{2}(b)$ in the Sevastopol Bay

According to the difference in the atmospheric and surface waters $p \mathrm{CO}_{2}$, one can conclude that the bay water currently absorbs carbon dioxide from the atmosphere, except for the summer period of 2014, when the water itself was a source of carbon dioxide (Fig. 5) which is typical for coastal water areas [17, 18]. The increase of $\mathrm{CO}_{2}$ concentration resulted in $\mathrm{pH}$ drop by 0.06 in 2008-2016. At the same time, in comparison with 1998-2005 $\mathrm{pH}$ has a wider range of variation limits (on average by \pm 0.08 ). The most obvious $\mathrm{pH}$ decrease is characteristic of the warm period (summer, early autumn), which is due to the intensification of organic matter oxidation and production of carbon dioxide, facilitating by an increase in temperature. Steady $\mathrm{pH}$ decrease in the surface layer indicates an unstable organic matter concentration growth, its active oxidation and $\mathrm{CO}_{2}$ concentration increase. It can also be a consequence of a decrease in primary production as a result of anthropo- 
genic pressure. $\mathrm{pH}$ decline in the bottom layer, especially in summer-autumn period, indicates the presence of additional organic matter source, which is bottom sediments. This is confirmed by previous work, according to which organic carbon abundance in the bottom sediments of the bay is $\geq 4 \%[2,4]$. Alk increase (by 4\%) from 2008 to the present time also reveals the growth of the contribution of the organic matter oxidation in the bottom layer and in the bottom sediments to the carbon cycle and formation of the current state of the Sevastopol Bay ecosystem.

According to $N O A A$ data [19], in 2016 atmospheric $p \mathrm{CO}_{2}$ value was $407 \mu \mathrm{atm}$. There is no linear increase in the variation of $p \mathrm{CO} 2$ of the surface layer of the Sevastopol Bay waters, however, the upward trend is obvious. By the variation of atmospheric $p \mathrm{CO}_{2}$ and $p \mathrm{CO}_{2}$ annual average values in the surface waters, it can be seen that the difference between them decreases (Fig. 5, $b$ ). This indicates the decrease in the carbon dioxide absorption by the Sevastopol Bay waters. Currently, this value has dropped by $6 \%$. It reached its minimum value in 2015 when we suggested that the regime of the bay would change by 2018 [5]. However, in 2016 this difference slightly increased (Fig. 5, b) and slowed down the observed trend in the decline of the bay ecosystem absorptive capacity.

Conclusion. Active development of the Sevastopol Bay, uncontrolled discharge of domestic wastewaters (often untreated) led to negative changes in its ecosystem. This is revealed most clearly in the summer period: due to a growth of anthropogenic load on the bay waters, the absence (or the minimum) hydrodynamic effect, a decrease in the solubility of gases, an increase of the fluxes of nutrients and organic matter, there is the most pronounced difference in the hydrochemical characteristics in the bottom and surface layers. In the autumn-winter period the bay waters are well mixed and their practically homogeneous vertical distribution is observed.

Distribution of nutrients and carbonate system components over the bay area is determined by the effect of the Chernaya River fresh waters in the inner part of the bay (the area of sea and river water mixing), sources of anthropogenic origin near the SDPP as well as discharge of wastewater without treatment and storm water sewage.

According to the results of the study, it can be drawn a conclusion about the predomination of anthropogenic component impact on the hydrochemical regime of the bay. This is manifested in:

- elevated (in comparison with the background values of the open part) concentrations of nutrients which approach or even exceed the MPC value;

- the growth trend of almost all nutrients, DIC and $p \mathrm{CO}_{2}$ in the bay waters by 2016 .

$p \mathrm{CO}_{2}$ value variation (more than by $30 \%$ ) indicates the change in the ratio of carbonate system components. Currently, the processes of organic matter oxidation determine the state of the Sevastopol Bay carbonate system.

Judging by the decreasing difference between the atmospheric and surface waters $p \mathrm{CO}_{2}$, there is a possibility that the bay ecosystem will soon serve as a source of carbon dioxide. The shift of equilibrium towards the organic component predominance in the natural cycles of the bay ecosystem will negatively affect not only its ecological state but also its recreational attractiveness.

PHYSICAL OCEANOGRAPHY VOL. 25 NO. 22018 


\section{REFERENCES}

1. Ivanov, V.A., Ovsyanyy, E.I., Repetin, L.N. and Romanov, A.S., 2006. GidrologoGidrokhimicheskiy Rezhim Sevastopol'skoy Bukhty i ego Izmeneniya pod Vozdeystviem Klimaticheskikh i Antropogennykh Faktorov [Hydrological-Hydrochemical Regime of the Sevastopol Bay and its Changes under the Influence of Climatic and Anthropogenic Factors]. Working paper. Sevastopol: MHI, 90 p. (in Russian, unpublished).

2. Orekhova, N.A. and Konovalov, S.K., 2009. Polarography of the Bottom Sediments in the Sevastopol Bay. Physical Oceanography, [e-journal] 19(2), pp. 111-123. https://doi.org/10.1007/s11110-009-9038-6

3. Moiseenko, O.G. and Orekhova, N.A., 2011. Investigation of the Mechanism of the LongTerm Evolution of the Carbon Cycle in the Ecosystem of the Sevastopol Bay. Physical Oceanography, [e-journal] 21(2), pp. 142-152. https://doi.org/10.1007/s11110-011-9111-9

4. Orekhova, N.A., 2010. Gipoksiya i Anoksiya v Donnykh Osadkakh Krymskogo Poberezh'ya [Hypoxia and Anoxia in Bottom Sediments of the Crimean Penensula]. Geography and Tourism, [e-journal] (4), pp. 146-152 (in Russian).

5. Orekhova, N.A., Medvedev, E.V. and Konovalov, S.K., 2016. Carbonate System Characteristics of the Sevastopol Bay Waters in 2009-2015. Physical Oceanography, [e-journal] (3), pp. 36-46. doi:10.22449/1573-160X-2016-3-36-46

6. Millero, F.J., 1996. Chemical Oceanography. 2nd ed. Boca Raton: CRC Press, 469 p.

7. Riebesel, U., 2004. Effects of $\mathrm{CO}_{2}$ Enrichment on Marine Phytoplankton. J. Oceanogr., [ejournal] 60(4), pp. 719-729. doi:10.1007/s10872-004-5764-z

8. Millero, F.J., 2007. The Marine Inorganic Carbon Cycle. Chem. Rev., [e-journal] 107(2), pp. 308-341. doi:10.1021/cr0503557

9. Zeebe, R.E. and Wolf-Gladrow, D., 2001. $\mathrm{CO}_{2}$ in Seawater: Equilibrium, Kinetics, Isotopes. Elsevier Oceanography Series, 65. Amsterdam: Elsevier, 360 p. Available at: https://imedea.uib-

csic.es/master/cambioglobal/Modulo_V_cod101611/Ocean\%20Sinks/biblio/CO2Zeebe\%26 Wolf_Cap1.pdf [Accessed 11 October 2017].

10. Heinze, C., Meyer, S., Goris, N., Anderson, L., Steinfeldt, R., Chang, N., Le Quéré, C. and Bakker, D.C.E., 2015. The Ocean Carbon Sink - Impacts, Vulnerabilities and Challenges. Earth Syst. Dynam., [e-journal] 6(1), pp. 327-358. doi:10.5194/esd-6-327-2015

11. Bordovskiy, O.K. and Ivanenkov, V.N. eds., 1978. Metody Gidrokhimicheskikh Issledovaniy Okeana [Methods of Hydrochemical Ocean Studies]. Moscow: Nauka, 271 p. (In Russian).

12. Bordovskiy, O.K. and Chernyakova, A.M. eds., 1992. Sovremennye Metody Gidrokhimicheskikh Issledovaniy Okeana [Modern Methods of Hydrochemical Ocean Studies]. Moscow: IO AN SSSR, 201 p. (in Russian).

13. Unesco, 1987. Thermodynamic of the $\mathrm{CO}_{2}$ System. In: Unesco, 1987. Thermodynamic of the Carbon Dioxide System in Seawater. Unesco Technical Papers in Marine Science, 51. Paris: Unesco, pp. 3-21. Available at: http://www.jodc.go.jp/jodcweb/info/ioc_doc/UNESCO_tech/077668eb.pdf [Accessed 15 October 2017].

14. Alekin, O.A. and Lyakhin, Yu.I., 1984. Khimiya Okeana [Ocean Chemistry]. Leningrad: Gidrometeoizdat, 340 p. (in Russian).

15. Kuftarkova, E.A., Subbotin, A.A., Rodionova, N.Yu. and Ivanov, V.N., 2007. Ekologicheskie usloviya vyrashchivaniya midiy v Sevastopol'skoy bukhte [Ecological conditions for mussel growing in the Sevastopol Bay]. In: MHI NANU, 2007. Ekologicheskaya Bezopasnost Pribrezhnykh i Shel'fovykh Zon i Kompleksnoe Ispol'zovanie Resursov Shel'fa [Ecological Safety of Coastal and Shelf Zones and Comprehensive Use of Shelf Resources]. ECOSIGidrofizika. Iss. 15, pp. 434-442 (in Russian).

16. Sverdrup, H.U., Johnson, M.W. and Fleming, R.H., 1942. The Oceans: Their Physics, Chemistry and General Biology. New York: Prentice-Hall, Inc., 1087 p. 
17. Raymond, P.A., Bauer, J.E. and Cole, J.J., 2000. Atmospheric $\mathrm{CO}_{2}$ Evasion, Dissolved Inorganic Carbon Production, and Net Heterotrophy in the York River Estuary. Limnol. Oceanogr., [e-journal] 45(8), pp. 1707-1717. doi:10.4319/lo.2000.45.8.1707

18. Borges, A.V., Schiettecatte, L.-S., Abril, G., Delille, B. and Gazeau, F., 2006. Carbon Dioxide in European Coastal Waters. Estuarine, Coastal and Shelf Science, [e-journal] 70(3), pp. 375 387. doi:10.1016/j.ecss.2006.05.046

19. NOAA, 2018. NOAA Satellite and Information Service. [on-line] Available at: ftp://ftp.nodc.noaa.gov [Accessed 20 October 2017].

\section{About the authors:}

Natalia A. Orekhova - Head of Marine Biogeochemistry Department, FSBSI MHI (2, Kapitanskaya Str., Sevastopol, 299011, Russian Federation), Ph.D. (Geogr.), SPIN-code: 9050-4772, ORCID ID: 0000-0002-1387-970X, ResearcherID: I-1755-2017, natalia.orekhova@mhi-ras.ru

Alla V. Varenik - Senior Research Associate, Marine Biogeochemistry Department, FSBSI MHI (2, Kapitanskaya Str., Sevastopol, 299011, Russian Federation), Ph.D. (Geogr.), SPIN-code: 3277-7914, ORCID ID: 0000-0001-5033-4576, ResearcherID: H-1880-2014, alla_chaykina@mail.ru

\section{Contribution of the co-authors:}

Natalia A. Orekhova - formulation of goals and objectives of the research, discussion of the results of the work, qualitative analysis of the results and their interpretation (carbonate system), analysis and generalization of the research results (carbonate system), formulation of conclusions (carbonate system), preparation of the article text (carbonate system)

Alla V. Varenik - discussion of the results of work, solution of organizational and technical issues on the text preparation, qualitative analysis of the results and their interpretation (nutrients), analysis and generalization of the research results (nutrients), formulation of conclusions (nutrients), preparation of the article text (nutrients)

All the authors have read and approved the final manuscript.

The authors declare that they have no conflict of interest. 